\title{
El (auto) tropicalismo en Costa Rica. Un análisis de la marca-país del Instituto Costarricense de Turismo dentro de la geopolítica del turismo
}

\author{
(Self) tropicalism in Costa Rica. An analysis of the country-brand \\ of the Costa Rican Tourism Institute within the geopolitics of \\ tourism.
}

\author{
Santiago Navarro Cerdas \\ Universidad de Costa Rica \\ San José, Costa Rica \\ sanacer@gmail.com
}

\begin{abstract}
RESUMEN. En la actualidad del turismo internacional las diversas regiones del planeta se dividen en clústeres de mercado especializados para la atracción del consumo de la experiencia que implica, esto a través de la constitución de "marcas-país". Es en este marco contextual que se realiza el presente análisis del discurso sobre la Responsabilidad Social Empresarial, los Certificados de Sostenibilidad Ambiental y la campaña oficial del Instituto Costarricense de Turismo (ICT) en el año 2012, en los cuáles los estereotipos de la imagen del trópico, del turismo de naturaleza, sol y playa se articulan con el aprovechamiento retórico de la imagen de la población local de Costa Rica como la del "país más feliz del mundo", hacia el maquillar las contradicciones sociales, laborales, culturales y ecológicas internas, siguiendo mitos sobre el excepcionalismo costarricense. Este proceso refleja una división global del sistema mundo (Wallerstein, 2005), en la cual los centros mundiales conforman "periferias del placer" (Ash y Turner, 1999), donde algunas se encuentran dentro del circuito geográfico tropical del planeta bajo imaginarios de exotismo (Beltrán, 2008) específicos, los cuales podríamos denominar como "tropicalismo". A la par de esto, siguiendo la lógica del "colonialismo interno" (Amin, 2009), las élites del Estado-Nación de estas regiones tropicales conforman el "auto tropicalismo", que es
\end{abstract}

Este es un artículo de acceso abierto publicado bajo los términos de la Licencia Creative Commons 4.0 Internacional Atribución-NoComercial-SinDerivadas.

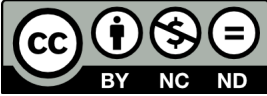


el construir la imagen local a semejanza de los deseos de ocio y fantasía que los centros globales conforman.

PALABRAS CLAVE: turismo, marca-país, tropicalismo, auto-tropicalismo, colonialismo, geopolítica.

\begin{abstract}
Currently, in the geopolitics of international tourism, the various regions of the planet prone to tourism are divided into specialized market clusters to attract the consumption of the experience, through "country brands". It is within this framework that the present discourse analysis of Corporate Social Responsibility, the Environmental Sustainability Certificates and the official propaganda of the Costa Rican Tourism Institute (ICT) in 2012, in which the stereotypes of the image of the tropic, nature tourism, sun and beach tourism are articulated with the rhetorical use of the image of the local population of Costa Rica as that of the "happiest country in the world", towards to makeup social, labor and cultural internal contradictions, following myths about Costa Rican exceptionalism. This reflects a clear global division, in which the world Centerst push the making of "peripheries of pleasure" (Ash and Turner, 1999) that are within the planet's tropical geographic circuit, under specific imaginary exoticism (Beltrán, 2008), which we could name as "tropicalism". Along with this, following the logic of "internal colonialism" (Amin, 2009), the political and economic elites of the Nation-State of these tropical regions develop what we could call "self-tropicalism", which is to build the image local similar to the desires of leisure and fantasy that global centers make up.
\end{abstract}

KEYWORDS. tourism, country brand, tropicalism, self-tropicalism, colonialism, geopolitics.

\title{
INTRODUCCIÓN
}

Desde los años 20 del siglo pasado Yolanda Oreamuno (1999) se mostraba crítica con lo que llamó "mitos tropicales" para imaginar "Costa Rica" como espacio para la mirada extranjera desde las agencias de turismo. Con el pasar de un siglo este tipo de mitos siguen expandiéndose y consolidándose, el Instituto Costarricense de Turismo (ICT) desde la segunda mitad del siglo pasado se vale de este tipo de imágenes para la atracción del turista internacional de alto poder adquisitivo. El presente artículo asocia esta utilización contemporánea de ciertos "mitos tropicales" en la configuración actual del discurso del ICT con la división presente del sistema-mundo entre centros y periferias (Wallerstein, 1999), 
principalmente como una reactualización del legado colonial con el uso del "exotismo cultural" y del "capitalismo verde" como formas cultural y económica dominante en función del turismo, lo que más adelante se observa que se configura en ciertas regiones del trópico del planeta como "tropicalismo", cuya contraparte interna para adecuarse a esa imagen externa correspondería al "autotropicalismo" como forma particular de "auto exotismo" y de configuración de cierta economía política a lo interno. Para ello se analiza la campaña oficial del ICT del periodo en estudio, así como la discursividad en dos ámbitos que destaca el ICT en el turismo costarricense, como son los Certificados de Sostenibilidad Ambiental y el Turismo Rural Comunitario.

El presente artículo se basa en un capítulo de la investigación realizada por el autor denominada " Costa Rica" como periferia del placer. Poder, colonialidad y resistencia en torno al turismo y la inmigración en playa Matapalo» ${ }^{1}$, en la cual se efectuó observación participante y entrevistas a personas migrantes trabajadoras de un mega hotel en construcción, a personas pobladoras locales y a turistas presentes en la comunidad de Sardinal, Guanacaste, así como un análisis del discurso de la propaganda oficial del Instituto Costarricense de Turismo (ICT) del 2012. De esta forma, en el presente artículo se profundiza en este último apartado sobre el ICT y, por tanto, intenta conservar las referencias académicas y de la web utilizadas en el periodo estudiado.

Durante los años 2011 y 2012 el slogan comercial de la marca-país, denominado "Sin ingredientes artificiales", fue suplementado con el "A million dollars gift of happiness", el cual es el que se analiza en el presente artículo. Posteriormente, a partir del 2013 hay un cambio en la marca-país hacia el eslogan "Esencial Costa Rica", la cual ha tenido mayor acogida que la campaña analizada en este artículo y permanece constante hasta la actualidad. De esta forma, se denota, como se verá más adelante, el vaivén de la lógica de consumo y mercadotecnia cambiante en estos procesos, según el ir y venir de la oferta y demanda internacional. Sin embargo, que el periodo de estudio haya sido el 2012 no limita la actualidad del análisis ya que, muchas de las tendencias de configuración del discurso turístico acá analizadas son de largo aliento.

1 Agradezco enormemente al Instituto de Investigaciones Sociales de la Universidad de Costa Rica el haberme otorgado la beca "Jóvenes Investigadores" durante el año 2012 para la realización de la investigación. 
La configuración de esta discursividad donde se tiende a mezclar la imagen de lo "no artificial", lo "esencial natural", junto a la "felicidad" interna de la población costarricense, tiene consolidación con el surgimiento, en los años noventa del siglo pasado, del discurso dominante del "desarrollo sostenible", visto como el desarrollo dentro del sistema capitalista que sería armónico con el ambiente natural y con la sociedad. Ligado a este proceso, la ONU y su vertiente enfocada en el turismo, que es la Organización Mundial del Turismo (OMT), hace suya esta doctrina, denominándola "turismo sostenible" (OMT, 2012) ${ }^{2}$. A su vez, el Estado costarricense a través del Instituto Costarricense de Turismo (ICT) ha convertido en dominante esta discursividad, en la promoción como un país "estrella" en el turismo sostenible, esto expresado principalmente en significantes como el "ecoturismo", la "responsabilidad social corporativa" y el "turismo rural comunitario", según se puede observar en la página web oficial ${ }^{3}$ y en la página oficial de Facebook ${ }^{4}$ del ICT en el periodo del presente estudio.

Un ejemplo de esta discursividad es lo que comenta el Ministro de Turismo en el 2011, Allan Flores (Córdoba, 2011) sobre la campaña publicitaria del ICT de ese momento:

Hoy hemos asumido el reto de apostar por la creatividad y la innovación. Es hora de que nos presentemos ante el mundo tal cual somos, un país con un marcado compromiso con la sostenibilidad, un destino elogiado por nuestra calidad de vida y principalmente por nuestro calor humano, un lugar que cautiva sorprende y enamora (párr. 4).

En el contexto reciente de la globalización, el enfoque neoliberal del turismo se consolida para Blázquez, Cañada y Murray (2011) con el Consenso de Washington a finales de los ochenta del siglo pasado, promovido por medio de la Reserva Federal norteamericana y el Fondo Monetario Internacional, estableciendo una hoja de ruta

2 Que la ONU tenga un brazo enfocado en el turismo es paradójico, ya que la ONU usualmente se enfoca en actividades directas sobre "derechos humanos", como en el caso de la UNESCO, el ACNUR, la OIM, UNFPA, etc., pero el vínculo con el turismo no se hace tan claro. Esto expresa igual el lugar de desproblematización que el turismo tiene el día de hoy como aparente lugar de poco conflicto socioambiental, más bien como herramienta de "desarrollo sostenible".

3 http:/ / www.visitcostarica.com/

4 http://www.facebook.com/visitcostarica?fref=ts 
para disciplinar a los países periféricos azotados por la crisis de la deuda externa, especialmente los latinoamericanos. El Estado en su vertiente neoliberal (Harvey, 2007) tiende a jugar un papel de validación, legitimidad y facilidad con el capital transnacional y su inversión desregulada. Este papel del Estado no se reduce solo a incentivar la inversión extranjera directa con inversión financiera pública, infraestructura física y jurídica que le facilite su desarrollo, sino que también se encarga de la constitución de la infraestructura de saber-poder (Foucault, 2006), es decir, de legitimación de una racionalidad específica acerca del uso/explotación de recursos laborales, naturales y sociales. Es en la tendencia dada por estos procesos globales que se da la configuración del turismo contemporáneo en Costa Rica.

En relación con lo anterior y en sintonía con la ola global alrededor del crecimiento exponencial del turismo desde la última parte del siglo anterior, Costa Rica pasa a conformar el turismo como la principal economía de exportación, por ejemplo, para el 2010 de un total de 9,340 millones en exportaciones, el turismo reporta 1.977 (representando un 21,2\%), el banano 675,1 y la piña 675,1 (ICT, 2010). Sobrepasando por bastante la economía agroexportadora usual, pero continuando una lógica de "economía de postres" en la que se apuesta el grueso de la economía a productos ligados al lujo y el ocio, lo cual deja vulnerable a que en momentos de crisis internacional los países del primer mundo que consumen estos productos (frutas, café, turismo) no los prioricen y, por ende, caiga la economía local, poniendo en condición crítica la soberanía alimentaria interna del país al depender del vaivén del mercado internacional.

En este contexto el turismo tiene un muy buen lobby político y económico, ya que al concebirse bajo la imagen de ser una "industria sin chimeneas" suele ser muy desproblematizado, suponiendo que sus efectos dañinos a la sociedad, la cultura, las subjetividades y la ecología son reducidos. Sin embargo, este artículo intenta ir en una línea contraria, al caminar hacia una mirada de problematización crítica de su establecimiento muchas veces rápido y poco reflexionado en el país, de ahí que se suma a una tradición crítica tanto desde movimientos sociales y comunidades como desde la academia, véase, por ejemplo, Blázquéz, Cañada y Murray (2011); Cañada (2011) y (2010); Castellón (2005); Castillo (2008); Cordero (2003), (2006) y (2008); Cordero y Montijn (2002); Raymond (2004); Rivers-Moore (2007); Harnecker y Lizana (2001); Morales 
et.al (2011); Ramírez (2008) y (2010), por mencionar algunos trabajos cercanos al periodo de la investigación.

El artículo se divide en ocho partes, un primer apartado metodológico, dos apartados iniciales sobre el contexto geopolítico en que se da la preminencia del discurso del turismo sostenible en Costa Rica con su marca-país, tres apartados de análisis de los discursos del ICT (sobre la campaña publicitaria, los Certificados de Sostenibilidad Turística y el Turismo Rural Comunitario), un análisis global que introduce los conceptos de tropicalismo y auto tropicalismo como configuraciones contemporáneas del legado colonial de exotismo, y las conclusiones.

\section{METODOLOGÍA}

La información se obtuvo de la página web oficial y de Facebook del Instituto Costarricense de Turismo durante los meses de marzo a diciembre del año 2012. Los procedimientos cualitativos de análisis utilizados implicaron (Valles, 1997):

1. Recolección de información presente en las páginas durante ese periodo, estas páginas fueron: A. El menú principal de la web oficial del ICT para analizar los componentes de la campaña "a million dollar gift of happiness", la cual incluye B. Visitación periódica del Facebook oficial ICT, así como los apartados en la web oficial sobre C. Certificados de Sostenibilidad Ambiental y D. Turismo Rural Comunitario.

2. Generación de categorías descriptivas con base a los segmentos: A. Campaña publicitaria del ICT, B. Certificados de Sostenibilidad Ambiental y C. Turismo Rural Comunitario.

3. Clasificación de contenidos con la detección de tendencias discursivas y contrarrestarlas.

4. Establecimiento de descripciones, comparaciones e interpretaciones comprensivo-explicativas sobre las categorías y contenidos surgidos con relación al contexto sociohistórico.

Este proceso se siguió junto a herramientas del análisis crítico del discurso de Parker (1996) y (2005), lo cual implicó determinar patrones de los textos no en sí mismos únicamente, sino en su articu- 
lación con el contexto sociohistórico en que surgen, en sus formas de interacción ideológicas con énfasis en las relaciones de poder y las resistencias sociales en ellas. Así, las cadenas lingüísticas se analizaron como atravesadas por el poder, por ejemplo, en separaciones por clase social, raza, nacionalidad o en separaciones identitarias entre el "ellos" y el "nosotros" en la discursividad. De ahí que el uso del análisis del discurso no se hace sobre la pretensión de entender las cadenas lingüísticas en su aparente "pureza" o "neutralidad" sino que implica un posicionamiento en el análisis que queda explícito para poder ser reflexionado, debatido y discutido.

\section{EL POSICIONAMIENTO DE LA MARCA-PAÍS EN EL MERCADO INTERNACIONAL}

Para el 2006 entre los 10 principales destinos de las personas ciudadanas de Estados Unidos en América destacaba Costa Rica en el octavo lugar, mientras que los restantes países de Centroamérica no aparecían en los primeros 25 lugares (Vargas, 2006). Esta tendencia continúa hasta la actualidad. Costa Rica es el principal atractivo turístico de América Central a nivel de cantidad de visitas anuales. Así, la estructura a nivel micro y macro del país se enfoca en esta promoción turística y pasa a ser esta actividad su principal fuente económica, como vimos antes (ICT, 2010).

Esta imagen de "Costa Rica" se muestra bajo la conversión en una marca-país, impulsada por el ICT, con el eslogan de "Sin ingredientes artificiales" y para el 2012 con el "Costa Ricas a million dollar gift of happiness". Lo específico de la oferta turística de Costa Rica: se enfatiza la naturaleza y es reconocida a nivel internacional como un gran destino del "turismo sostenible", como efecto diferenciador con el mercado más cercano, que es el centroamericano. Para Hellín y Martínez (2009), una marca-país en el turismo se convierte en un vehículo a través del cual se identifica la oferta para el mercado mundial del consumo turístico, se le presenta de forma atractiva, intentando subjetivamente provocar deseo y generar expectativas positivas. Conformando una suerte de "personalidad" única y diferenciada que sea atractiva para la demanda, por lo que su función es lograr un posicionamiento deseado en la subjetividad de quienes son potencialmente consumidores. Esta marca pretende, expresan los mismos autores, un buen posicionamiento en la vigente economía del "consumo de la experiencia" (especializa- 
ción de la economía de servicios) muy importante en la actualidad del capitalismo donde la publicidad juega un papel fundamental, creando una imagen global y homogénea de una región determinada.

Donaire (2012) resalta lo crucial del juego semántico en la publicidad y mercadotecnia previa al viaje turístico, ya que debe de tener la capacidad de generar el deseo, de incentivar fantasías, sobre el consumo del ocio que implica el turismo. Esto supone la presencia en revistas especializadas de turismo, páginas web, publicidad, videos de Youtube, plataformas como Instagram y Facebook, así como imaginarios y estereotipos "boca en boca" sobre las imágenes de cómo es el destino, por lo que el marketing del turismo y la configuración de su mirada específica supone ir a encontrar lo que ya se sabe que se va a encontrar al lugar turístico, lo que le vendió la publicidad (la gente no tiende a pagar grandes sumas de dinero para ir al otro lado del mundo a un lugar desconocido que no llene sus fantasías o no le dé la misma foto de Instagram que ya vio previo en miles de otras personas). Aquí el lugar de la publicidad como "pantalla de la ideología" que analiza Žižek (2004) desde el psicoanálisis, es fundamental. Para él, la fantasía no es algo así como una suerte de realidad paralela que se crea para compensar lo que la realidad concreta no provee, más bien cumple la función inversa, la fantasía es lo que da el marco de coordenadas para lo que se concibe como realidad concreta.

En todo esto, es crucial la capacidad de generar el suficiente efecto de atracción que impulse el gasto de dinero y se consoliden las expectativas de un ocio garantizado, particularmente, interesa acá en los periodos de vacaciones y de invierno en el norte del globo que empuja la búsqueda de lugares con turismo natural y de sol y playa en el sur del globo, en particular la franja tropical. Esta relación entre países es crucial en el turismo, ya que se instaura en las lógicas del funcionamiento de la economía global actual. Para ello es importante, retomar lo que Wallerstein (2005) define como sistema-mundo, visto como la consolidación expansiva del capitalismo como sistema principal de producción de valor, en esto el capital tiende a ir ignorando fronteras y tiende a extraer las riquezas (el trabajo y la naturaleza) desde los países más periféricos en beneficio de los centrales. En este sistema-mundo se tiende a la unificación del modo de producción, pero no necesariamente a la total unificación política y cultural, por lo que es diferenciado la forma 
en que cada país y región hacen arreglos con respecto a la expansión de su funcionamiento.

Todo este proceso implica la articulación de todo turismo local con la lógica global del mundo a través de Cadenas Globales de Producción del turismo como actividad económica mundializada (Cordero, 2006), las cuáles suponen una división tajante entre centros y periferias con sus relaciones desiguales de poder, donde los centros mundiales acaparan la mayor parte de beneficios socioeconómicos (ahí se ubican la gran parte de las actividades de mayor valor, por ejemplo, las personas accionistas y ahí se determinan las principales decisiones de las transnacionales) y las periferias luchan entre ellas por los pocos recursos que quedan. Advirtiendo esta distribución desigual en el mundo, Ash y Turner (1991) proponen la noción de "periferias del placer" para dar cuenta de este lugar de las periferias turísticas de ser el lugar de ocio para el primer mundo.

Esta especialización se denota en que, para el año 2010 y 2011 Costa Rica fue considerada por la prestigiosa empresa de branding (que se encarga del proceso de construcción e invención de una marca comercial) internacional FutureBrand en colaboración con BBC World News, como la mejor marca-país de Latinoamérica. Future Brands resaltó la belleza natural (puesto número 5 en el mundo), su sistema de valores (puesto 25 de 113 países) y su imagen de protección al medio ambiente (Prensa Libre, 2010).

Para los años 2011-2013, el ICT destinó un presupuesto de $\$ 6,4$ millones para la promoción de la marca-país en Estados Unidos y Canadá, la cual, en palabras de Allan Flores, ministro de Turismo, busca atraer una demanda de personas con un capital económico y cultural específicos: personas "muy bien educadas y de altos ingresos que, además, tengan un alto sentido de conciencia ecológica" (Arce, 2011). Según el ICT esta campaña publicitaria se basa en índices que ponen a Costa Rica como la nación "más feliz del mundo", de esto que la estrategia publicitaria se llame "Costa Rica, a million dollar gift of happiness", cuya traducción podría ser: "Costa Rica, regalo millonario de felicidad". Esta campaña ha sido producida por la agencia estadounidense de publicidad 22square y fue lanzada en Facebook ${ }^{5}$, en Twitter y en iPads. En estos medios se pueden observar anuncios en vídeo y audio de la campaña, donde

${ }^{5}$ Puede encontrarse en www.facebook.com/visitcostarica 
las imágenes aluden en su mayor medida a la "biodiversidad" y "tranquilidad" del "costarricense" (más adelante se ahondará en el análisis de estos anuncios). Asimismo, el ICT expresa en su página oficial dos formas de expresión de "sostenibilidad": una de ellas va más directamente a lo "ambiental", como son los Certificados de Sostenibilidad Turística (CST) y el otro es más directamente "social", se trata del incentivo al Turismo Rural Comunitario $^{6}$, los cuáles se analizarán más adelante.

\section{EL CONTEXTO DEL DISCURSO “SOSTENIBLE" DEL ICT}

Rodríguez (2011) resalta que hoy se puede ver en la industria publicitaria global la amplia gama de imágenes con motivos naturales, animales exóticos, bosques exuberantes, árboles, etc. Toda gran empresa que quiera tener réditos con una buena imagen ha de contar en sus productos con formas "ecológicas", "verdes" o "sostenibles". Para él esta variación en la economía actual se debe a los movimientos mundiales hacia una estrategia donde las empresas y organizaciones intentan mostrar un gran interés por las problemáticas ambientales y el futuro de la humanidad. Nos dice que esto responde a un andamiaje comunicativo, un proceso complejo de mercadeo, que da en el clavo con el juego semántico de lo políticamente correcto en una época histórica donde el capital necesita hacer un ajuste con lo "ecológico", lo "verde", lo "sostenible" y la "responsabilidad social".

Así, para Rodríguez (2011) el ajuste reside en integrar la naturaleza y la sociedad como bienes escasos en el campo de los valores de uso y de cambio. Gran parte de este cambio se debe a que los mismos grandes impactos ambientales globales a la vez lesionan las posibilidades de acumulación de las grandes empresas, por lo que ellas mismas se ven en la necesidad de conservar alguna parte del ambiente y la sociedad, para su misma sostenibilidad. De esta forma, nos expresa, se conforma el "capitalismo verde", el cual vendría a considerar al mercado como el principal medio para responder a la crisis ambiental, integrando consideraciones ambientales en la economía, la producción y creando nuevos mercados aparentemente "verdes y limpios", que a la vez ayudan a apaciguar las resistencias sociales por factores críticos que crearían disidencia,

${ }^{6}$ Puede consultarse la página oficial del ICT en esta materia: http://www.turismo-sostenible.co.cr 
como el agua, la soberanía alimentaria y la defensa del territorio. En este proceso Rodríguez (2011) señala que es el BID (Banco Interamericano de Desarrollo) en conjunto con la CEPAL (Comisión Económica para América Latina), los principales organismos que han formulado e impuesto este tipo de economía en relación con la crisis climática.

Se puede observar la reconversión semántica del discurso de lo "ambientalista" y lo "responsable socialmente", que en algunas de sus expresiones pasa de ser un discurso de la disidencia social (principalmente entre los años setenta y ochenta del siglo pasado) a ser un discurso dominante integrado al sistema social hegemónico (principalmente a partir de los noventa del siglo pasado), como parte de ciertas subsunciones particulares del capital (Marx, 2008) que el neoliberalismo realiza actualmente, es decir, el proceso en que bienes públicos y comunes (como la naturaleza, las conformaciones culturales intangibles, el trabajo no asalariado) pasan a ser parte de la lógica del capital siempre en reconversión. A este respecto resulta crucial la noción de "conversión" que Montero (2006) toma de la teoría de la psicología de las minorías activas, la cual se refiere a las formas de disuadir el discurso disidente de las minorías sociales, por lo que las mayorías se apropian de ese discurso alternativo a su favor y lo incorporan a su discurso. Esto mismo, en términos de Van Dijk (2008), sería un proceso de cooptación, de apropiación de los discursos disidentes por los poderes dominantes

Esta carga semántica de lo "eco", lo "verde" se viene a complementar con la noción de "Responsabilidad Social", también en auge en esta época histórica. Se trata de la parte "social" de esta reconfiguración de la cara del capital. La Responsabilidad Social Corporativa (RSC), para Ramiro y Pulido (2009) ha sido también un vuelco paradigmático en la economía global. Para ellos, estas formas de responsabilidad social han formado parte históricamente en el capitalismo, siguen la lógica de la filantropía vista como caridad y asistencialismo, pero la RSC implica una especificación. El concepto de RSC surgió hasta los años 50 (Ramiro y Pulido, 2009), en un cambio histórico donde esa lógica filantrópica, que antes era usual en una pequeña élite social, se expande en la sociedad y poco a poco pasa a formar parte de las inversiones económicas que a largo o mediano plazo le da réditos a una gran cantidad de empresas. Asimismo, les ayuda a dar factores para apaciguar los movimientos 
sociales de resistencia, un gran agente que históricamente les ha descubierto y resistido a sus abusos. Nuevamente, se da un proceso de conversión (Montero, 2006) y cooptación (Van Dijk, 2008) de luchas sociales.

En este contexto, el turismo se instala en Costa Rica desde la segunda mitad del siglo anterior, desde un lugar de mucha desproblematización (Cañada, 2011). Como ejemplo de este uso discursivo, podemos ver la propaganda oficial de la transnacional RIU en su página web oficial de Costa Rica (RIU, 2012), expresa su noción de "Responsabilidad Social Corporativa" que se divide en tres áreas: gestión medioambiental, acción social y recursos humanos. En torno a la gestión medioambiental expresa:

La empresa es consciente de la necesidad de que el desarrollo de su actividad se realice con el adecuado respeto por el medio ambiente, por lo que se compromete al cumplimiento de los siguientes principios ambientales a través de diversos proyectos: 1. Racionalizar y hacer buen uso de los recursos naturales. 2. Mejorar continuamente y prevenir la contaminación. 3. Actualizar continuamente el programa ambiental. 4. Adecuar continuamente el cumplimiento de la legislación y reglamentación ambiental aplicables. 5. Promover la formación ambiental y la sensibilización de equipo humano que compone la empresa, así como de los clientes. (RIU, 2012, p. 4)

En torno a la acción social escriben:

El compromiso de RIU Hotels \& Resorts con la comunidad y los clientes se materializa en los siguientes proyectos: 1 . Política de patrocinio y colaboraciones 2. Apoyo a comunidades locales... 3. Compromiso contra la explotación sexual infantil.... 4. Dar continuidad a los proyectos solidarios... entre otras iniciativas (RIU, 2012, p. 4)

Esto contrasta con que RIU tiene el megahotel más grande de Centroamérica en playa Matapalo, Guanacaste, Costa Rica, y que al construirlo hizo diversos daños a los ecosistemas, realizó explotación laboral a migrantes en su construcción y expropiación de bienes comunes locales, también durante su construcción recibió gestos de resistencia y protesta por parte de las comunidades aledañas (Navarro, 2013).

Ramiro y Pulido (2009) sostienen que en esta lógica la relación 
de los Estados con las empresas se basa en una paradoja, ya que los Estados fomentan la RSC, pero sucede que la misma RSC ha devenido en una forma de sustituir el rol de la inversión social que los mismos Estados venían haciendo en épocas previas al neoliberalismo actual. Así, la RSC sustituye el rol que antes tenía el Estado de garantizar desarrollo social, comunitario y laboral, haciéndolo muchas veces de manera precaria. Esto responde a un tipo de reconversión de la concepción de la inversión social, que ahora pasa a manos de las empresas y forma parte de la lógica global del capital para crear beneficios económicos y acumulación y reducir el papel del Estado en actividades sociales (Ramiro y Pulido, 2009).

\section{ANÁLISIS DE LA CAMPAÑA “COSTA RICA COMO REGALO MILLONARIO DE FELICIDAD".}

En los primeros años de la década del 2000 el ICT lanzó la exitosa campaña publicitaria del eslogan "sin ingredientes artificiales" que, como vimos, colocó a la marca-país en el puesto número uno de Latinoamérica en el 2010 y 2011. Para los años 2011-2013, tras considerar que la particularidad de la marca-país se estaba viendo amenazada por otros lugares que también hacían referencia a ser lugares excepcionales para el turismo ambiental que alude a lo "no artificial" (Rivers-Moore, 2007), se decide lanzar la campaña "Costa Rica, a million dollar gift of happiness", oficialmente en inglés sin ninguna traducción oficial al español (sesgando de entrada el público al que va dirigida). Este rápido cambio nos demuestra la volatilidad del mercado turístico, su constante cambio por la búsqueda y creación de nuevos nichos de mercado que den la peculiaridad de cada lugar.

Para Ramón (2012), esta permutación del paso del eslogan "sin ingredientes artificiales" al "Costa Rica, million dollar gift of happiness" en el mercadeo de la marca país, se deben a los cambios en los hábitos de los turistas extranjeros tras las resacas de la crisis iniciada en el 2008, la cantidad de turistas sigue ampliándose (cerca de los 2 millones por año) pero disminuyen sus días de estadía y el gasto promedio. Esto ha hecho que la estrategia comercial busque turistas con mejor posición económica en Estados Unidos (mercado del que más se depende, teniendo en promedio cerca del $55 \%$ de los visitantes) y Canadá. 
Imagen 1. Portada del Facebook del ICT en el 2012

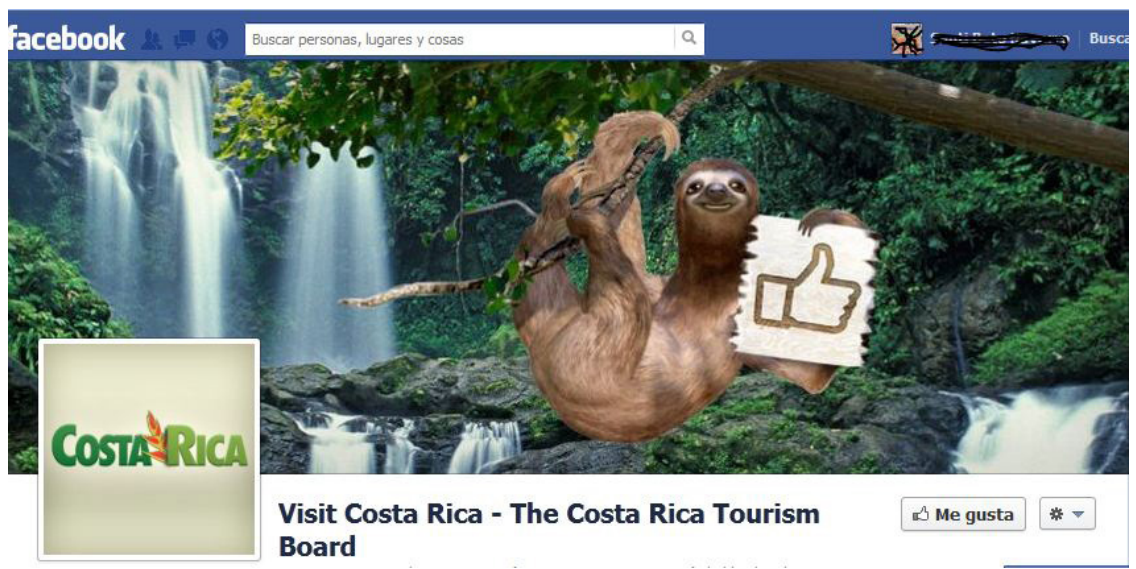

Fuente: extraída del Facebook del ICT en el 2012: www.facebook.com/visitcostarica

Esta estrategia publicitaria es efectuada por la firma publicitaria estadounidense 22squared ${ }^{7}$, que está encargada de las cuentas de Marriott Internacional, Orlando y Toyota, y según su página web oficial $^{8}$, es una de las seis agencias independientes más importantes de Estados Unidos. Al respecto la directora de Mercadeo del ICT, María Amalia Revelo, expresó "su experiencia en turismo, las buenas recomendaciones de sus clientes y una visión compartida en materia de sostenibilidad, así como el establecimiento de relaciones a largo plazo con sus cuentas, fueron claves en la escogencia de esta firma" (Revista Summa, 2011). La estrategia de la campaña se basó en el Índice del Planeta Feliz' ${ }^{9}$ el cual mide aspectos como el bienestar que auto perciben los y las habitantes, la esperanza de vida y la huella ecológica y concibe a Costa Rica como el "país más feliz del mundo" (Rodríguez, 2012).

En la primera fase de la campaña se efectuó una promoción durante cinco meses (desde octubre del 2011 y hasta febrero del 2012), que se centraba en las redes sociales, debido a que ese público de ingresos altos que se pretende buscar es altamente tecnológico y de esta manera se intenta llegar a ellos de forma efectiva. La promoción consiste en que los cibernautas participen en rifas de viajes

7 Puede verse en la página oficial de la empresa: http://www.22squared.com/ tags/million-dollar-gift-of-happiness/

8 http://www.22squared.com/who-we-are/agency-model/

9 www.happyplanetindex.org 
al país. Los viajes se obsequiaron mediante Facebook, regalando un viaje por día, hasta completar 80 viajes para una persona y un acompañante. En la página web se pueden observar los "testimonios" de estas personas beneficiadas.

María Amalia Revelo, explicó que la campaña promoverá la sostenibilidad del destino turístico, ya que, para conformar los paquetes de viajes, se eligieron empresas turísticas con los niveles más altos de la Certificación para la Sostenibilidad Turística. Esto expresa el deseo de diferenciación de la marca-país, no solo en cuanto a eslogan sino a esta innovación entorno a la forma de hacer publicidad interactiva, ella expresa que:

Las campañas de promoción de otros destinos son muy parecidas entre sí, por lo que nosotros queremos romper con ese paradigma $\mathrm{y}$ diferenciarnos. Tenemos una misión claramente definida $\mathrm{y}$ es compartir la felicidad de los costarricenses. Con esta campaña amplificaremos la voz de las personas que recomiendan a Costa Rica como destino turístico, logrando un efecto multiplicador que genere réditos a nuestra industria turística y experiencias inolvidables para quienes nos visitan. (Tecnitur, 2012)

$\mathrm{Al}$ dar un vistazo a la página oficial en Facebook y ver los comentarios de las personas que han visitado Costa Rica se denota una constante reafirmación de la propaganda oficial, a partir de estas imágenes pacificadas con la naturaleza y la sociedad, cercanas a la imagen paisajística naturalista de la geografía paradisíaca (Rivers-Moore, 2007).

La publicidad efectuada por 22squared para la primera promoción de regalar viajes a Costa Rica, presenta dos videos oficiales, el primero muestra la promoción y las razones de porqué Costa Rica es el país más feliz del mundo ${ }^{10}$ y el segundo muestra los lugares que se pueden visitar en Costa Rica ${ }^{11}$. En el primer video promocional, denominado "Costa Rica vacation places", de una duración de un minuto y trece segundos, se puede observar la siguiente secuencia: el video inicia indicando que la localidad es playa Manuel

10 Puede verse en Youtube: http://www.youtube.com/watch?v=zM4UmZMpuWU\&feature $=$ relmfu

11 Puede verse en http://www.youtube.com/watch?v=PROtaG6aKlM\&featu$\mathrm{re}=\mathrm{relmfu}$ 
Antonio con la siguiente imagen:

Imagen 3. Mr. Sloth en Manuel Antonio.

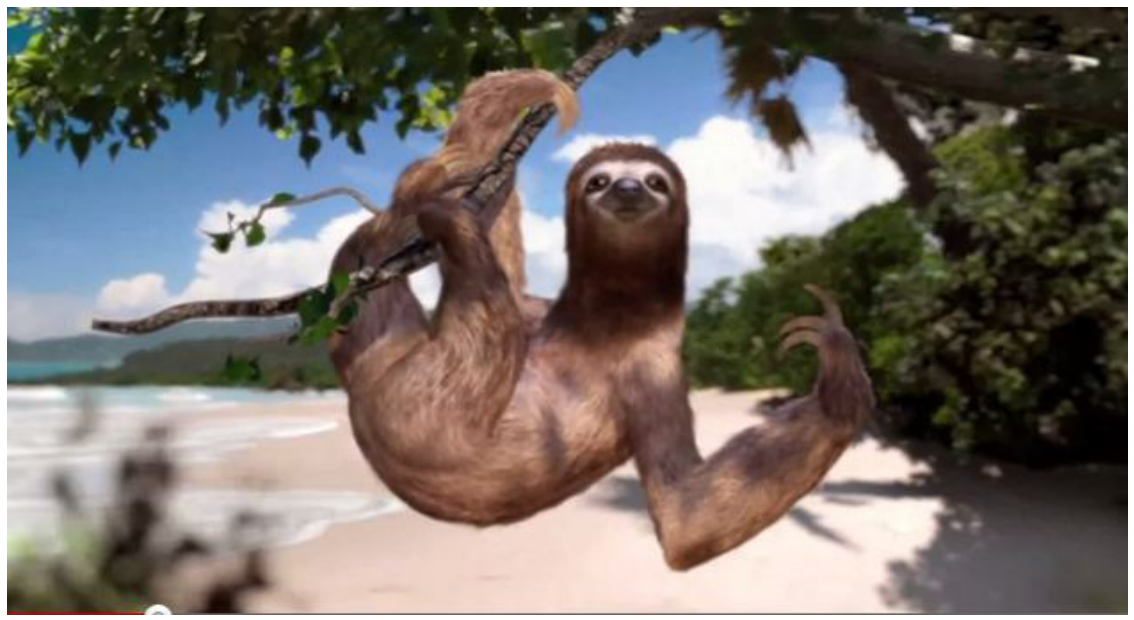

Fuente: imagen extraída del canal de Youtube del ICT en el 2012: http://www.youtube. $\mathrm{com} /$ watch? $=\mathrm{zM} 4 \mathrm{UmZMpuWU} \&$ feature $=$ relmfu

En idioma inglés se presenta el personaje principal "Mr. Sloth" (el Sr. Perezoso), el cual habla muy lento en una actitud relajada. Se introduce diciendo "hola americanos" y comenta que vive en el "país más feliz del mundo, Costa Rica", expresa que en los siguientes meses van a dar los viajes de la promoción, que en total tienen un costo de un millón de dólares. A continuación, expresa que alguna gente le pregunta "¿por qué Costa Rica es tan feliz?", y responde que es simple: " 1 . Nosotros tenemos el $5 \%$ de biodiversidad en el mundo" (en ese momento aparece la imagen de un mono y una tortuga). “2. Tenemos dos océanos", “3. Somos friendly locos". Luego aparece la imagen de una persona que interactúa con Mr. Sloth, diciéndole que "Mr. Sloth es guapo" (con un intento de sentido del humor, al insertarle en la imagen de su cara la boca de oso perezoso de Mr. Sloth, donde se teatraliza que es manipulado por él), esta es la imagen: 


\section{Imagen 4. Costarricense zoomorfizado en Mr. Sloth.}

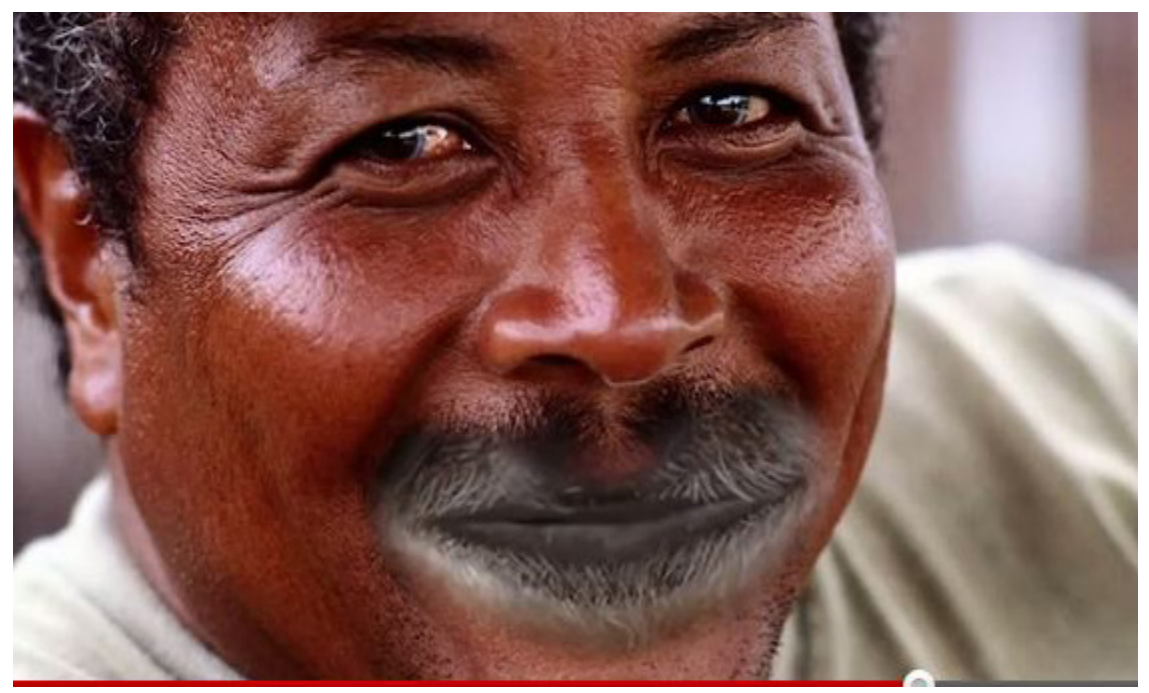

Fuente: imagen extraída del canal de Youtube del ICT en el 2012: http://www.youtube. $\mathrm{com} /$ watch? $\mathrm{v}=\mathrm{zM} 4 \mathrm{UmZMpuWU \& feature=}=\mathrm{relmfu}$

Cuando trata de decir el punto 4 se cae de la rama (mostrando torpeza) y dice que habla "sloths" (perezoso o con pereza). El siguiente video, de 55 segundos de duración, al inicio está ambientado en el Volcán Arenal, en él Mr. Sloth expresa que va a mostrar lugares del "país más feliz del mundo":

Imagen 5. Mr. Sloth mostrando el volcán Arenal

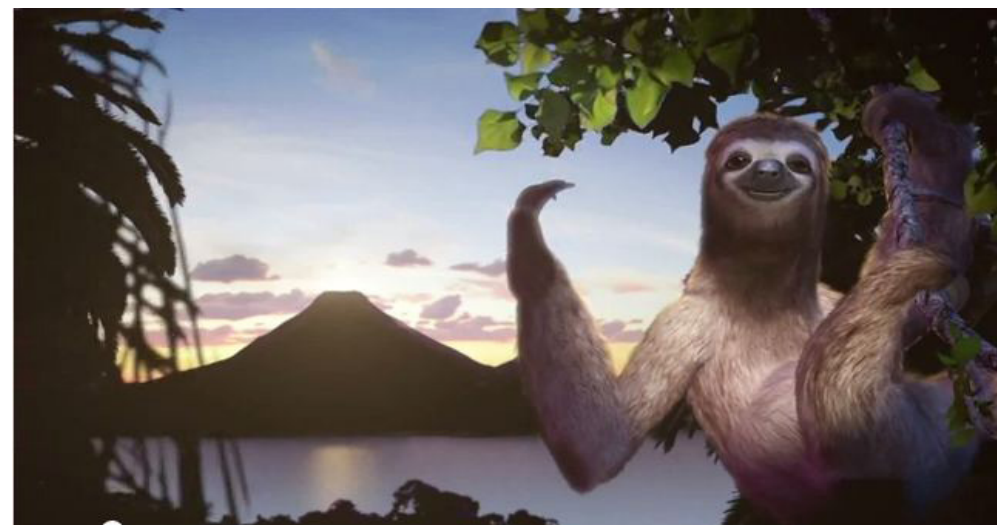

Fuente: Imagen extraída del canal de Youtube del ICT en el 2012: http:/ /www.youtube. $\mathrm{com} /$ watch?v=zM4UmZMpuWU\&feature $=$ relmfu 
Inicia con Playa negra y luego, denotando su lentitud, se dirige a San José, que menciona como una "Meca de riqueza cultural".

\section{Imagen 6. Mr Sloth mostrando San José}

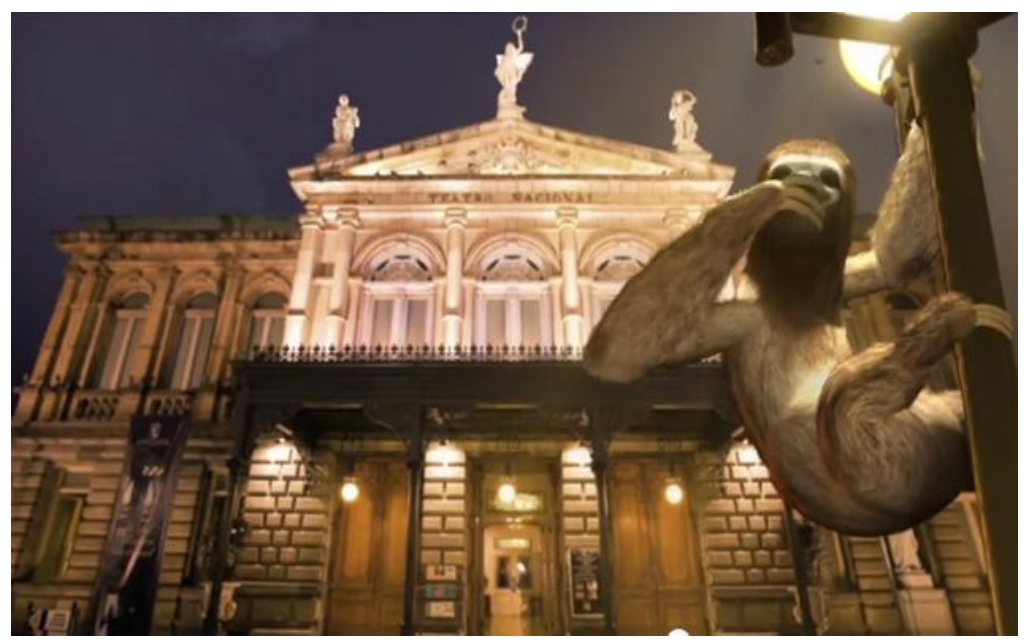

Fuente: Imagen extraída del canal de Youtube del ICT en el 2012: http://www.youtube. $\mathrm{com} /$ watch? $\mathrm{v}=\mathrm{zM} 4 \mathrm{UmZMpuWU} \&$ feature $=$ relmfu

En los dos videos, en la presentación del lenguaje verbal y el de imagen, se denotan varios rasgos reiterativos del lenguaje oficial del ICT, como un lugar de "exótica naturaleza" y gente muy "relajada y amable". Se muestran lugares naturales bajo la visión estándar de la exuberante naturaleza, punto que es crucial a la hora de enumerar los factores de la felicidad costarricense, junto a los factores más psicologizados del costarricense: su relax (y el "hablar perezoso") y el ser amistoso ("friendly loco" del humano zoomorfizado en oso perezoso, sin dejar de notar su piel oscura como elemento racial). El "nosotros" que muestra el ICT corresponde al turista internacional, es quien es activo en la intención, a quien se busca identificar con el mensaje. El "otro" de la enunciación se convierte en el poblador local y la "naturaleza" local, como un lugar pasivo, sin contradicciones, exótico pero domesticado al mismo tiempo (lejano, pero sin presentar peligro ni riesgo), sin tensiones sociales ni culturales ni ecológicas. 
Como lo muestra Žižek (2004), la pantalla (internet, televisión, celular) representa ese espacio por excelencia de la sociedad actual de depositar fantasías sociales, partiendo de esto se denota que en los videos se da esa conjunción de la imagen del lugar ecológico y del lugar feliz, el humano zoomorfizado da muestra de esa unificación metonímica fantasiosa (naturaleza y sociedad en una sola conjunción pacificada, domesticada). Más adelante ahondaremos en mayor profundidad en estos lugares de enunciación, ya que omiten el "plus" o "exceso" del lado oscuro del poder que suponen.

\section{ANÁLISIS DE LA ESTRATEGIA DISCURSIVA DE LOS CERTIFICADOS DE SOSTENIBILIDAD TURÍSTICA DEL ICT}

La noción de "desarrollo sostenible" tomó auge en la entrada del nuevo siglo en la industria turística como vimos, forma en la actualidad parte de grandes transnacionales del turismo como TUI (a la que pertenece la transnacional RIU) y Thomas Cook. En el 2008, el Consejo Global de Turismo Sostenible (GTSC) determinó unos criterios básicos de certificación. El proceso de certificación del ICT en el 2012 se instala dentro de esta línea de estandarización de lo que se considera turismo sostenible, dando cuatro puntos de sostenibilidad (es un proceso de 5 niveles de categorías de sostenibilidad, representadas por hojas verdes, paralelas a las 5 estrellas hoteleras): 1. Entorno físico-biológico, 2. Planta de servicio (hospedaje) y gestión de servicio (operadoras turísticas), 3. Cliente y 4. Entorno socio-económico (básicamente actividades de "responsabilidad social" con las comunidades cercanas) ${ }^{12}$. En la página web del ICT se pueden leer que aquellas empresas que obtienen el certificado tienen descuentos para participar en ferias internacionales y si tiene la categoría de 5 niveles tiene su espacio gratis en el stand de Costa Rica.

Existen una serie de críticas básicas que pueden hacérsele a estos Certificados de Sostenibilidad Turística (CST). Gisolf (2012) desarrolla algunos:

1. Elevado costo de implementar todas las medidas. Cuanto más grande el hotel, más fácil le es satisfacer los requisitos, ya que

12 Estos criterios se pueden encontrar en el apartado de sostenibilidad del ICT en el periodo del estudio en https://www.ict.go.cr/es/sostenibilidad/cst.html 
supone gastos que los pequeños hoteles no están en capacidad de implementar, así las iniciativas en pequeña escala y de participación comunitaria no califican.

2. La validación con CST tiende a deslegitimar a empresas que no lo tengan como no "sostenibles" aunque lo sean, como podría ser el caso claro de pequeñas empresas ecológicas. También el sistema de clasificación por cinco niveles da esos criterios de (des)legitimación, controlados más que todo por la capacidad de una empresa de invertir en los altos costos de la CST.

3. Los estándares de los requisitos para la CST vienen de países del primer mundo, de un sistema turístico global dominado por las grandes transnacionales. Este proceso no permite incidir en la particularidad de cada contexto sociocultural.

Notamos que la concepción de "turismo sostenible" por parte del ICT, va acorde con el desarrollo antes mencionado del capitalismo verde, donde se mantienen las características básicas del sistema capitalista en el cual domina el capital transnacional (muchas de las veces con la lógica de enclave ya mencionada) en detrimento de formas más comunitarias. En la página oficial del ICT del 2012 sobre estos certificados podemos ver que entre los hoteles acreditados se encuentran grandes megaproyectos que van de las 200 a las 500 habitaciones, varios de los cuales han sido blanco de movimientos de resistencia comunitaria en contra de sus abusos (Cañada, 2010). Entre los hoteles que la tienen se encuentran hoteles como el Fiesta Resorts y Spa, el Four Seasons en el complejo concesionado Papagayo, el Paradisus Playa Conchal, el Barceló Langosta Beach, entre otros.

Entonces, la publicidad con la información dada discursivamente por el ICT supone la imagen de la población local y comunitaria como secundaria y pasiva para ostentar los CST, es decir, los sectores locales de clase baja y media no tiene mucha voz ni cabida en esta lógica. Dentro de este lugar de enunciación, como sujetos no cumplen un rol predominantemente activo, creativo, de promoción de un intercambio social, cultural y económico igualitario, sino que, para ser competitivos, se deben de adecuar a estándares internacionales, tanto semánticos como económicos. 


\section{ANÁLISIS DE LA ESTRATEGIA DISCURSIVA DEL TURISMO RURAL COMUNITARIO DEL ICT}

El Turismo Rural Comunitario corresponde al otro discurso de mercadeo en la página oficial del ICT. Si los certificados de sostenibilidad corresponden a la parte ambiental, este corresponde a la parte "social" y "cultural" de este posicionamiento. Este turismo ha tenido un auge en Latinoamérica en los últimos años y tiene su origen en las críticas sociales y ambientales que se le han hecho al sistema masivo del turismo convencional (Cañada, 2011). Se establece así la promoción de formas más locales y micro que evitan los desastres ambientales y culturales que pueden tener los enclaves turísticos masivos (solo el hecho de construir un hotel de entre 300 y 500 habitaciones es un gran impacto ambiental y probablemente una lógica no socialmente solidaria con la comunidad en que se instala). Esto da pie a la posibilidad de que se den formas más solidarias y locales de establecer una empresa, de una manera que podríamos ser más "sostenible" que la establecida en los criterios de "sostenibilidad ambiental" antes mencionados, al dar mayor garantía de que los recursos generados sean mejor distribuidos,

El ICT en la página $w^{13} b^{13}$ se expresa que el Turismo Rural Comunitario (TRC):

Este tipo de turismo permite integrar las riquezas naturales, la vida cotidiana de la comunidad rural y la dinámica propia de las actividades agropecuarias, en un producto atractivo para el mercado turístico nacional e internacional... Se caracteriza, además, por ofrecer a los y las visitantes un contacto personalizado. A diferencia del turismo rural ofrecido por otros países, las empresas de turismo rural comunitario en Costa Rica, por su dinámica comunitaria y la escala de su actividad, para articular un producto turístico requieren de la participación de varias familias o de la comunidad en su conjunto.

Un análisis global del turismo en Costa Rica (Cordero, 2002), (Ramírez, 2010), denota que este tipo de turismo no es el de mayor auge en el país, donde, como demuestra Ramírez, predomina el "ecoturismo masivo". Es paradójico que el mismo ICT llevó a cabo un cuestionario a todos los turistas que salían del país por

13 Se puede encontrar en la web oficial durante el periodo de estudio https:// www.ict.go.cr/es/informacion-institucional/desarrollo-turistico.html 
aeropuertos en los años entre 2006 y 2010 (ICT, 2011), donde se les preguntó si efectuaron alguna: "visita a una comunidad rural y compartió con los habitantes actividades, tradiciones y estilos de vida (actividades agrícolas, tradiciones culturales y ambientes naturales)". Estas características formuladas en la pregunta se refieren a las del Turismo Rural Comunitario. En el 2006 solo un 3,7 \% de los turistas totales respondieron que sí habían visitado un lugar así y para el 2009 un $5.5 \%$ (ICT, 2011).

Tampoco necesariamente responde a las características de una actividad realmente "alternativa", debido a las capacidades de la volatilidad del mercado global de crear muy diferentes mercados para "todos los gustos". Así, una persona en un viaje turístico puede visitar un lugar de turismo comunitario y en el siguiente viaje un mega hotel 5 estrellas, de esta forma estos dos mercados se complementan no siendo necesariamente alternativos, sino complementarios en una lógica de visión del turismo global.

Ahora bien, existe otra situación comúnmente desapercibida alrededor de la noción de turismo comunitario, ya que si bien esta forma evita para las y los pobladores locales (comúnmente indígenas y personas campesinas rurales) los desastres sociales y ambientales de los megaproyectos con lógica de enclave (las personas locales se ven más beneficiadas ${ }^{14}$ ), por otro lado, persiste un agente desproblematizado en esta visión, se trata del mercado que demanda este tipo de turismo, del turista que lo utiliza. Como vimos antes, según Allan Flores Ministro de Turismo, el ICT busca atraer a personas de altos ingresos y esta es una recomendación de organismos internacionales, agencias de cooperación y grupos empresariales. Se limita así el consumo interno de turistas locales y de bajos ingresos.

Hay razones económicas para justificar que sea a este público al que vaya dirigido (Cañada, 2011), como el hecho de que al tener mayor poder adquisitivo que el turista de las regiones más locales se pueden tener mayores beneficios por un menor volumen de turistas (menos turistas pero pagan más), también el que sea un público que pueda costear un transporte a lugares comúnmente de difícil acceso alejados de las zonas urbanas, así como el factor cul-

14 Lo cual también es problemática ya que en las comunidades donde se instaura puede tender a acrecentar las contradicciones sociales dentro de ella, siendo algunas familias las beneficiadas y excluidas otras, produciendo cierto elitismo. 
tural de que las personas de los países periféricos tienden a no estar "acostumbradas" a realizar actividades turísticas en la naturaleza o a "valorar" las expresiones culturales.

\section{Imagen 7. El Turismo Rural Comunitario promocionado por el ICT.}

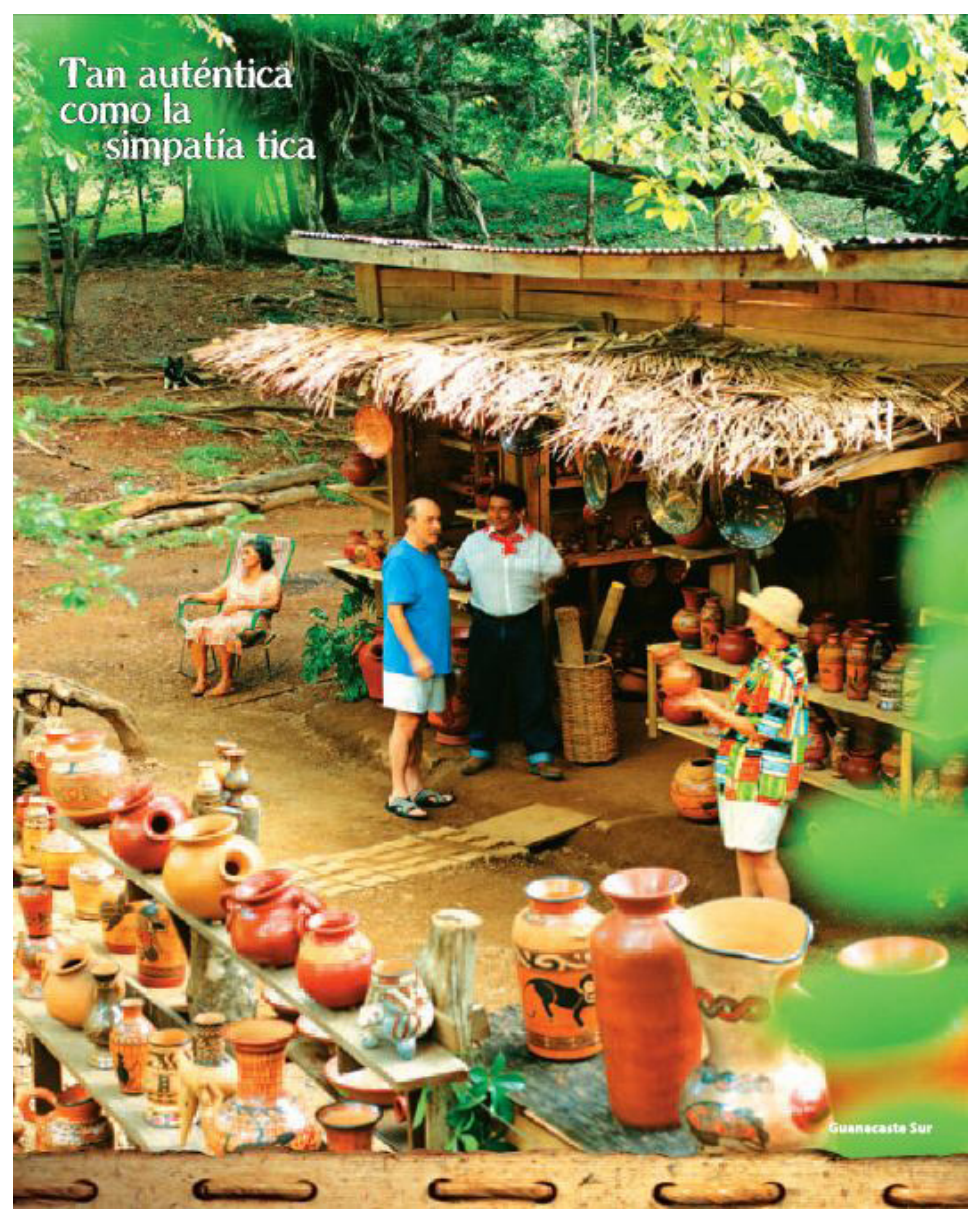

Fuente: Puede verse en el periodo de estudio en la página oficial del ICT: www. visitcostarica.com

Sin embargo, al darle énfasis a este público se puede seguir reproduciendo la insostenibilidad y el elitismo del turismo, aspectos que ponen en duda sus supuestos de fácil celebración. Cañada (2011) ofrece algunos puntos para sustentar esto. Dar esa prioridad 
a sectores de altos ingresos implica disponer de infraestructura material de construcción alejada de la habitual lo que ha de tender a ser fuente de endeudamiento o dependencia de recursos externos. Asimismo, el segmento de turistas usual es internacional, que se desplaza en avión de grandes distancias con fuertes efectos ambientales por el uso masivo de gasolina. Esto conlleva de nuevo a una dependencia de las volatilidades del mercado internacional (que varíe los gustos de las modas turísticas o que en una crisis en el primer mundo las posibilidades económicas no den para efectuar turismo). También se da un riesgo de una extensión de la dependencia de estructuras turísticas comunitarias con respecto a la gran empresa turística, principalmente de operadores turísticos, que por lo común han de mediar la proyección internacional de las comunidades (el mercadeo indispensable para que alguien en lugares lejanos se muestre con interés). Vemos en la siguiente imagen, el lugar de la persona local con la frase "tan auténtica como la simpatía tica", reforzando esta lógica de la persona local tranquila y entorno cómodo.

La perspectiva del TRC es un intento y avance importante con respecto al lugar pasivo y dependiente de las configuraciones locales con respecto al turismo internacional y el capital transnacional. Sin embargo, la lógica global de funcionamiento de la estrategia discursiva del ICT sigue siendo prioritaria para continuar una relación desigual entre la perspectiva de los centros mundiales sobre las periferias que generan turismo. Siguiendo a Cañada (2015), es importante un cambio paradigmático en la forma de ver el Turismo Rural Comunitario, lo cual supondría activar el turismo cercano local de clase media y baja, en detrimento del internacional, junto a la apropiación comunitaria de los procesos de mediación a los mercados posibles. Esto propiciaría mayor voz activa a los sectores locales.

\section{EL TROPICALISMO Y EL AUTO TROPICALISMO EN LA DISCURSIVIDAD DEL ICT COMO FORMAS DE (NEO) COLONIALIDAD.}

En los tres análisis anteriores sobre el discurso del ICT (su campaña publicitaria, su estrategia de Certificados de Sostenibilidad Turística y de Turismo Comunitario), vemos una estrategia global del ICT en su intento de atracción del turista del primer mundo ha- 
cia el consumo de la experiencia a través de su marca-país. En este desenvolvimiento, la población y la naturaleza locales cumplen un rol publicitario para esto, usualmente son ubicados en un lugar pasivo, de curiosidad, de interés, exótico, pero desde una distancia que los debe de ubicar en un lugar sin conflictos, sin contradicciones, de domesticación, "felices". Este lugar se acerca al de la noción de exotismo, el cual ha sido utilizado en contextos donde se da una relación colonialista entre centros y periferias del globo.

Para Beltrán (2008), siguiendo a Said (2002), el exotismo es una conformación social donde se construye un "nosotros" desde un lugar que visualiza un "otro" ubicado en lo "exótico". Este "otro" se le construye como un lugar reverso, lo "que no somos" o, mejor, lo que "se ha dejado de ser". Así, se usa un discurso en el que el "nosotros" se ubica en un lugar "ingenuo" o "inocente" o "autocrítica" para visualizar de una manera "bondadosa" y "curiosa" al "otro". Sin embargo, siempre se persiste una relación jerárquica donde el "nosotros" se entiende desde una posición superior civilizatoriamente sobre el "otro". Se mantiene una distancia entre el "nosotros" y los "otros" que tiene una presentación de buena intención, de interés, de curiosidad, de valoración. De esta manera, es una "buena" forma de mantener una distancia no igualitaria que continúa uno de los legados coloniales de la conquista en los siglos pasados, donde no se ve al "otro" periférico desde una superioridad muy explícita, directa y agresiva, sino desde un lugar más pasivo y sutil.

Esta imagen del "otro" local se acerca a la mitología histórica del "buen salvaje" popularizada en Rousseu (Todorov, 2003), el cual no suponía ver negativamente de manera explícita a los pueblos colonizados, pero si suponía mantenerlos en una imagen romántica llena de prejuicios y estigmas "bonachones", es decir, al mostrarse como una forma "buena" de mirada hacia los pueblos colonizados de alguna manera se distinguía del racismo explícito de una buena parte de la dominación colonial e imperial. Visto así, este lugar del "buen salvaje" se relaciona con la noción de exotismo vista anteriormente, como ese lugar de condescendencia romántica sobre el "otro" que paradójicamente se encarga de sostener una distancia jerárquica de superioridad de parte del "nosotros" que le mira. Las imágenes sobre la población local que hemos analizado con el tropicalismo del ICT, ese lugar de la población "feliz", domesticada, pasiva, que no representa problemas ni contradicciones, tiene una 
relación estrecha. De esta manera el tropicalismo se relaciona a una tradición de formas de dominación más "blandas" del legado colonial, que más adelante se verán.

\section{Imagen 9. Afiche publicitario con naturaleza exuberante y personas}

\section{felices.}

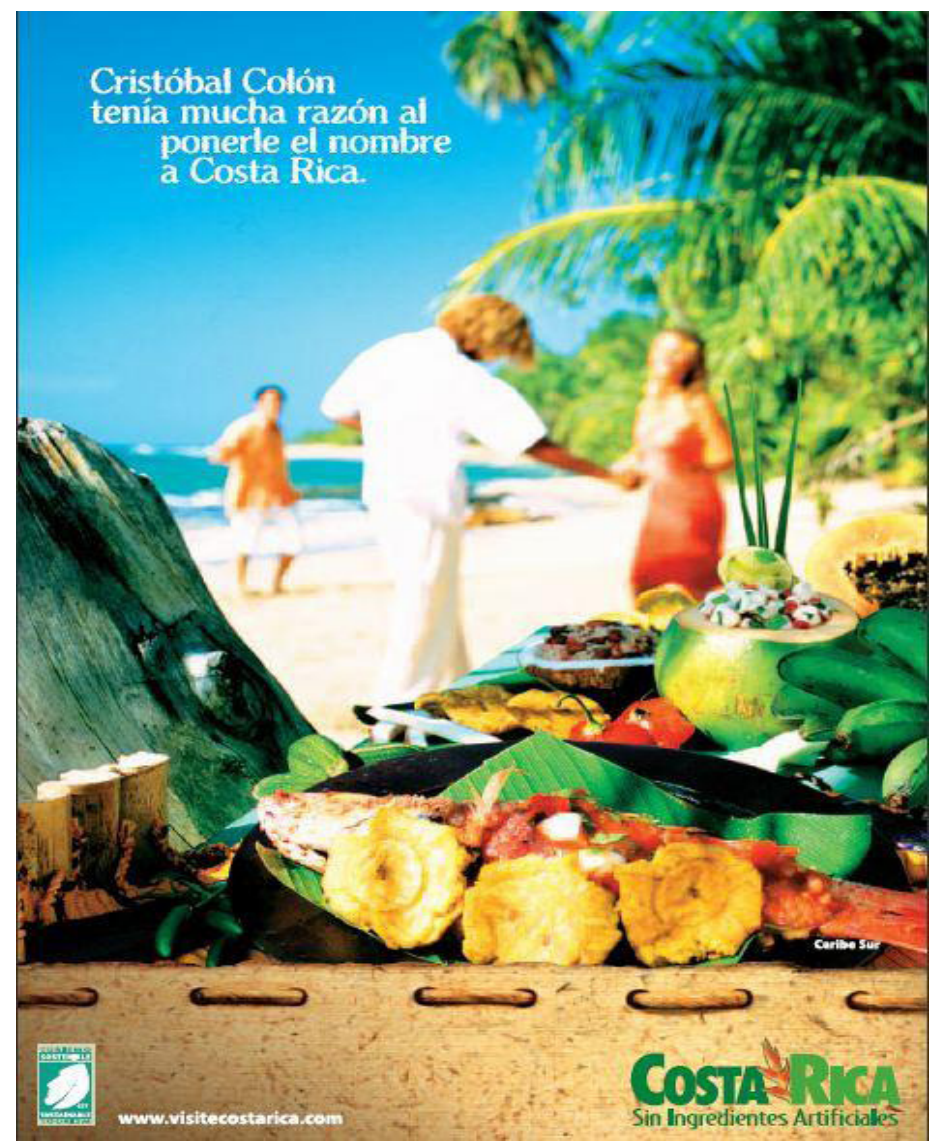

Fuente: Puede verse en el periodo de estudio en la página oficial del ICT: www. visitcostarica.com

A la par de esta imagen de la persona local, es reiterativo en la propaganda el uso de imágenes de playas con palmeras, arena blanca, personas pobladoras tranquilos, árboles frutales, bosques frondosos, animales exóticos, que los vincula a nociones de una "naturaleza idílica" y de "paraíso natural". La naturaleza cumple 
un rol complementario de esa imagen "prístina" e "inocente" acerca del espacio local (Rivers-Moore, 2007). De esta manera, podemos concebir que los discursos (visuales y escritos) predominantes en el ICT se enlazan a un exotismo particular vinculado a su lugar en el trópico del planeta, lo cual podríamos denominar como "tropicalismo". Como expresa Said (2002) históricamente los sectores dominantes del planeta han construido simbólica y materialmente espacios geográficos que expresan más sus deseos propios que el entendimiento y comprensión mutua. Así, se conforma el tropicalismo como ese lugar donde se configura un deseo y una mirada sobre la población y la geografía de las zonas tropicales del planeta. Ahí el exotismo se mezcla con un proceso de domesticación, es decir de mostrar al "otro" local y la "naturaleza", en un lugar pacífico, sin problemas, en desmerito de las contradicciones socioambientales que supone la realidad local.

De esta forma, el tropicalismo cumple funciones performativas (Butler, 2005), lo cual supone concebir su discurso como práctica, es decir, un lugar de enunciación de ciertas palabras centrales que alimentan el conformar realidades simbólicas y materiales particulares. Así, el lenguaje es un acto que no solo ha de reflejar la realidad, sino que también ha de tender a construirla, jugando un papel importante en la constitución de subjetividades, identidades, estereotipos, geografías, espacios, etc. ${ }^{15}$ Este tropicalismo como reinvención del legado colonial se expresa, a nivel de texto e imagen, en el siguiente afiche presente en la página web del ICT en el 2012 se expresa que "Cristóbal Colón tenía mucha razón al ponerle el nombre a Costa Rica" enmarcado en imágenes llenas de exotismo tropical y el eslogan de "Costa Rica sin ingredientes artificiales":

Esta persistencia del exotismo en el discurso del ICT hasta el día de hoy supone la permanencia de las relaciones coloniales a nivel global a pesar de que las independencias jurídico-formales ya se dieron en la mayor parte del planeta desde el siglo pasado (Quijano,

15 Esto no supone considerar que solo con la intención discursiva de algunas personas o sectores las realidades se pueden construir de manera voluntaria y maleable infinitamente, como ciertas visiones posmodernas tienden a dar a suponer, haciendo una extensión de la fantasía (neo)liberal del sujeto autónomo que controla el mundo a su elección (Eagleton, 1999; Gruner, 2002), sino supone considerar que las palabras en las relaciones sociales cumplen un peso importante al adecuar las percepciones, las acciones, los hábitos y hasta las geografías y espacios con ciertas ideas dominantes, principalmente desde los sectores que tienen más poder sobre los que tienen menos.

\section{3}

Anuario del Centro de Investigación y Estudios Políticos, ISSN: 2215-2873

Núm. 11, enero-diciembre, 2020: 87-123. DOI: 10.15517/aciep.v0i11.42419 
2000). Históricamente, la consolidación de la dominación imperialista y colonialista de parte de los centros mundiales sobre los Estado-Nación periféricos supuso procesos de "colonialismo interno" (González-Casanova, 2006; Amin, 2002). Es decir, procesos donde las élites internas de cada país se alían con las élites internacionales para consolidar la domesticación interna de posibles disidencias al proyecto modernizador (usualmente movimientos indígenas, afrodescendientes, campesinos y de trabajadores/as). Así, las periferias no se conforman como un lugar pasivo, sino que tienen conflictos internos entre los sectores que se alían con la dominación transnacional y sectores disidentes, por lo que la función de las ideologías dominantes es garantizar que la disidencia interna se apague. De esta manera, si el tropicalismo supone algunos de los discursos e imágenes con las que el primer mundo ha tendido a conformar las franjas tropicales del planeta, podemos concebir al "auto-tropicalismo" como una las formas en que las élites internas asumen un lugar de construcción activa la reproducción de la relación colonial, el cómo se constituyen como "periferias del placer" (Ash y Turner, 1999) cumpliendo sus fantasías.

La configuración del auto-tropicalismo como continuidad de lógicas propias del colonialismo interno, supone una ambivalencia constante al interior de las poblaciones locales, lo cual se muestra cercano a estos lugares de resistencia o de complicidad con respecto a los poderes dominantes coloniales. Este proceso de cómo el sujeto colonizado asume su lugar como tal, ha sido analizado por Fanon (2009) y posteriormente Bhabha (2002), quiénes utilizan la noción de "identificación" psicoanalítica para denotar la ambivalencia que vive el sujeto colonizado, en la tensión entre asumir el lugar de la mirada que le da el colonizador (asumiendo su deseo de ser "como él", que se muestra históricamente en las narrativas de "blanqueamiento" del nacionalismo costarricense y la desproblematización del turismo como un tipo de migración) y el de resistirse a ella (odiando por ejemplo, el racismo que sufre por su color de piel). Por ejemplo, Costa Rica recibe al año más de dos millones de turistas a lo largo del año, esto supone cerca del 30-40\% de la proporción de la población total del país de 6 millones de habitantes. Por otro lado, la inmigración en el país ronda las 500 mil personas. El porqué se problematiza ante la presencia de migrantes y no la de turistas, viene atravesado por consideraciones de clase, raza, nacionalidad, nada ajenas a este tipo de conformaciones históricas de la 
relación colonizador / colonizado.

Bhabha (2002) toma de Lacan la noción de "mimesis", y la concibe como el proceso psíquico del sujeto dominado (subalterno o colonizado) que se identifica ambivalentemente con el sujeto dominante (o colonizador) en un vínculo de amor y odio, identidad y rechazo, narcisismo y agresión. Así, la "mimesis" del sujeto subalterno para Bhabha no es la total interiorización de la mirada colonizadora, sino el proceso interno en tensión y ambivalente de asumirlo en parte.

Se percibe acá la complejidad de las diversas y múltiples formas de configuración de los poderes en juego en el auto tropicalismo. Se configura como una forma de promover el exotismo desde lo interno de un país periférico con imágenes estereotipadas del trópico acerca de su naturaleza y de su población, también, va ligado a la necesidad de la corrección política empresarial (de darle gran valor a significantes "ecos" y "sociales") e irá a imponerse según el contexto específico en que las empresas quieran desarrollarse. Su forma de implantación dependerá mucho si son lugares que puedan encontrar resistencia tanto comunitaria-popular como estatal, resistencia ante la cual una gran estrategia es mostrar esta cara "humana" del capital. En ciertos contextos con poca resistencia contrahegemónica, las empresas y los Estados pueden imponer fácilmente sus lógicas de despojo más directamente, que en formas donde se necesite la sutilidad de ser políticamente más correctas.

Esta distinción sobre el uso del poder más "blando" o más "duro" según el contexto, lo podemos asociar a cuando Mignolo (2005) establece una distinción entre el imperialismo como la forma de dominación más represiva y agresiva de la conquista de las colonias (prácticas de genocidio y guerra, destrucción de la naturaleza) y el colonialismo que implicó procesos más de búsqueda de la imposición por el uso de mecanismos más cercanos a la política tradicional (establecimiento de regímenes de gobierno, leyes, normativas, saberes, para la legitimidad de la esclavitud, la explotación laboral y la extracción de la naturaleza como materia prima). Así, las relaciones de dominación en el sistema-mundo moderno históricamente se dividieron entre las formas de conquista más "blandas" y las más "duras". Estas "dos caras" también responden a las nociones del poder en Foucault (2006), por un lado, la represiva e impositiva llena de autoritarismo y la otra más sutil que da una buena cara a ese autoritarismo (la sociedad de control foucal- 
tiana con una lógica que, podría decirse, se presenta más "horizontal"), donde el poder no se muestra directamente en un carácter "represivo" sino más bien "productivo" cercano a esa parte de la dominación con base en la conformación legitima de un "sentido común" que es lo que, mucho antes, Gramsci llamaba como hegemonía (Gramsci, 1986). Por supuesto, estas dos caras del poder no son dicotómicas, más bien se interrelacionan continuamente en un juego de interacción estratégica y que son usadas tácticamente según la situación concreta.

En apartados anteriores veíamos como la conformación del "capitalismo verde" y de "desarrollo sostenible" que están en la base de conformación de los Certificados de Sostenibilidad Ambiental y la filantropía privada de la Responsabilidad Social Empresarial del ICT. Se denotó que estas formas corresponden a procesos de "reconversión" del capital a formas más sutiles de integración y dominación en el campo económico, con la cara del "buen capital", del "capitalismo con rostro humano". Por lo que las formas económicas del tropicalismo en el ICT corresponden a las configuraciones más "blandas" del poder del capital. Sin embargo, como denotamos antes, las formas "blandas" están interrelacionadas con las formas "duras", no corresponden a dicotomías, por lo que cierto lado más "oscuro" corresponde a lo no dicho en la discursividad del ICT, lo que omite.

En Hellín y Martínez (2009) la mercadotecnia por su propia naturaleza tiende a mostrar fantasías de completitud, sin faltas, fallas, contradicciones, al final si se quiere que alguien del otro lado del mundo gaste mucho dinero se le debe de presentar una fantasía de confort, una burbuja de placer. El ICT no muestra los excesos propios de los lugares "oscuros" del turismo, como el turismo sexual con menores de edad, la trata de personas, el narcotráfico, la destrucción del ambiente, la explotación laboral de mano de obra migrante para la construcción y los servicios en todo el globo turístico o la mercantilización y ausencia de la voz activa y participativa de las comunidades locales en que se instala.

Žižek (2004) denomina "la cara oculta del poder" a ese exceso de todo poder que sobrepasa sus propios términos explícitos y se torna obsceno, por lo que lucha por permanecer implícita, no dicho. Se trata de una suerte de complemento subterráneo e implícito 
que da la base para que las maneras formales o explícitas en que el poder se presenta a sí mismo funcionen con normalidad. Así, este exceso no es una excepción, es una condición de su funcionamiento. Para Žižek (2004), esta es la forma de poder en la que se especializa el psicoanálisis, que no son la figura del poder del derecho y la formalidad, sino que responde a esas lógicas que se manifiestan fuera de la vida pública y sus normas establecidas, es decir a las formas del super-yo, visto este no como pura representación de la moralidad social, sino como suplemento excesivo de las formas de normalización moral con que se da la socialización ${ }^{16}$. En este proceso, cuando aquél poder formal se subjetiviza y funciona en el sujeto, se le expresa una falla, su condición de no-todo, ahí es donde se debe de apoyar en su parte "ilegal", el lugar del goce superyóico (recordemos la complejidad de la ambivalencia del sujeto en la noción de mímesis antes mencionada).

Tomando en cuenta esto, en el análisis del discurso del ICT es importante el resaltar lo no dicho en su promoción de la marca-país y ante la configuración del tropicalismo a través de las vertientes del "capital bueno", el "colonialismo bueno", "el racismo bueno", etc., por lo que es fundamental la generación de la pregunta sobre el "plus" o "exceso" que se va a tender a generar a su lado. De esta forma, nos insiste Žižek (2005) es fundamental no dejar de denotar que la lógica misma de la legitimación de la dominación para ser efectiva debe permanecer oculta, así la ideología dominante se presenta como una totalidad que requiere insistentemente borrar las propias condiciones, contradicciones, tensiones, faltas, internas de su misma imposibilidad ${ }^{17}$.

16 En psicoanálisis, el aparato psíquico se divide en yo (la apariencia de un lugar de control consciente del sujeto), super-yo (la moral y culpa social internalizada en el sujeto) y ello (las pasiones más indomesticadas e incorrectas que permanecen en el sujeto), estas tres partes tienen una interrelación constante y en movimiento (por ejemplo, véase Freud, 1984). Asimismo, el "goce" o "jouissance" hace referencia a lo que está más allá del placer y moviliza al sujeto hacia donde se orienta su subjetividad escindida (por ejemplo, véase Žižek (2005))

17 La noción de "tropicalismo" acá esbozada no quiere reducir su análisis a los aspectos culturales que implica, sino también la economía política que supone, por lo que tiene como interés sobrepasar las divisiones usuales en el análisis del turismo entre estudios que hacen énfasis en la economía política y los que hacen énfasis en los aspectos culturales e identitarios. También entre los análisis que ven excluyentes la utilización de la tradición marxista y la de tradiciones postestructuralistas y postcoloniales. Si bien este no es el lugar, considero siguiendo a Grüner (2002), que esas dicotomías son innecesarias, lo cual no supone ignorar las tensio-

\section{7}




\section{CONCLUSIONES}

El análisis de la discursividad del ICT en el año del 2012 nos permite concluir que la conformación de la marca-país supone la utilización de estereotipos usuales sobre el trópico y su población, es decir imágenes de la naturaleza y las personas desde lugares pasivos, exóticos, domesticados. Se vende una discursividad de una población "feliz", "tranquila", "pura vida", de una naturaleza "conservada", "paradisíaca" y de una gestión del turismo "sostenible" y promotora de la comunidad y cultura local. Este conjunto de significantes se integra para dar con una imagen global que intenta condensar el eslogan "Costa Rica, regalo millonario de felicidad" que va dirigido hacia la población de Estados Unidos, Canadá y Europa. En gran parte de esta discursividad la población y la naturaleza locales tienen un rol que propicia la imagen de que la persona turista no tendrá que lidiar con problemas, contradicciones, tensiones, que dañen la imagen de fantasía que se vende.

El análisis crítico de esta discursividad oficial supone ubicarla en una conformación de la geopolítica del turismo global, donde las marcas-país suponen la generación de una mercadotecnia específica en el mercado global del consumo de experiencias, lo cual supone una continuación de las relaciones de poder desiguales del sistema mundo, entre centros y periferias. Estas relaciones utilizan estereotipos usuales históricamente en las relaciones coloniales de poder, como es la conformación del exotismo, cercano a la idea de "buen salvaje". Este exotismo se particulariza para las regiones tropicales del planeta que el turismo resignifica con "mitos tropicales" sobre la naturaleza paradisíaca y población local domesticada y feliz, lo que podríamos llamar como tropicalismo. Asimismo, el auto tropicalismo sería una versión del "colonialismo interno" histórico, donde las élites locales continúan los intereses de las élites de los centros mundiales, como es el caso del funcionamiento de la discursividad del ICT en los análisis. Por último, esto supone la importancia de analizar las diferentes formas de funcionamiento del poder, donde el tropicalismo muestra explícitamente su lado más

nes inevitables que hay a nivel epistemológico en este intento, posiblemente fallido. En este sentido el análisis "sintomático" que Žižek (2005) resalta a partir de cómo "Marx inventó el síntoma" para Lacan es fundamental, es decir, el vínculo de la "plusvalía" marxista con el "plus-de-goce" lacaniano resulta punta de lanza. 
"sutil" y "blando", a través de nociones como el "desarrollo sostenible" o "marketing verde", queriendo constantemente dejar en lo implícito el lado "duro" del poder, así como el lado "oscuro" que es condición de sus gestiones, como es la anulación en la discursividad de los excesos en los que algunas veces incurre el turismo como la explotación laboral, la destrucción de la naturaleza, la poca participación de la voz local y comunitaria, la burbuja inmobiliaria, entre otros.

\section{FUENTES CONSULTADAS}

Amin, S. (2009). Introducción. Frantz Fanon en África y Asia. En Frantz Fanon, Piel negra, máscaras blancas. Madrid: Akal.

Arce, S. (2011, 7 de Octubre). ICT promocionará al país en redes sociales y en las iPads. La Nación. http://www.nacion.com/2011-10-07/Economia/ ict-promocionara-al-pais-en-redes-sociales-y-en-las--ipad.aspx?Page $=2$

Ash, J. y Turner, L. (1991). La horda dorada. El turismo internacional y la periferia del placer. Madrid: Endymion.

Bhabha, H. (2002). El lugar de la cultura. Londres: Routledge.

Blázquéz, M.; Cañada, E. y Murray, I. (2011). Búnker playa-sol. Conflictos derivados de la construcción de enclaves de capital transnacional turístico español en El Caribe y Centroamérica. Scripta Nova Revista Electrónica de Geografía y Ciencias Sociales, Vol. XV, núm. 368. http:// www.ub.edu/geocrit/sn/sn-368.htm

Beltrán, J. (2008). Orientalismo, autoorientalismo e interculturalidad de Asia Oriental. En Pedro San Ginés Aguilar. Nuevas perspectivas de investigación sobre Asia Pacífico. Granada, España: Universidad de Granada.

Bourdieu, P. (1999). Las formas del capital. Lima: Piedra Azul.

Butler, J. (2001). Mecanismos psíquicos del poder. Teorías sobre la sujeción. Madrid: Cátedra.

Castellón, L. (2005). Percepción sobre el impacto del turismo en los valores sociales y la vida comunal de un grupo de pobladores de la comunidad de Villareal de Santa Cruz, Guanacaste. [Tesis de Grado Universidad de Costa Rica no publicada] Licenciatura en Psicología.

Castillo, S. (2008, 29 de abril). Estudio sobre impacto del crecimiento hote- 
lero e inmobiliario en Guanacaste exige orden en el sector. El Financiero. http://www.elfinancierocr.com/ef_archivo/2008/mayo/04/negocios1517693.html

Cañada, E. (2010). Turismo y conflictos socio-ambientales en Centroamérica. Managua: Enlace.

Cañada, E. (2011, 16 de agosto). ¿Debe el Turismo Comunitario orientarse hacia el mercado de altos ingresos?. http://www.albasud.org/blog/ es/213/iquest-debe-el-turismo-comunitario-orientarse-hacia-el-mercado-de-altos-ingresos

Cañada, E. (2015). La comercialización del turismo comunitario en América Latina. Anuario de Estudios Centroamericanos, Universidad de Costa Rica, 41, 159-189.

Cordero, A. (2006). Nuevos ejes de acumulación y naturaleza. El caso del turismo. Buenos Aires: CLACSO.

Cordero, A. (2008). La serpiente que se muerde la cola. Turismo y violencia social. Manuscrito sin publicar.

Cordero, A. (2003). El turismo y la dependencia latinoamericana. Anuario Social y Político de América Latina y el Caribe, 6, 104-111

Cordero, A. y Montijn, L. (2002). Turismo sostenible en Costa Rica. El caso de Quepos-Manuel Antonio. San José: FLACSO.

Córdoba, J. (2011, 6 de octubre). Costa Rica rifará viajes para atraer turistas de Canadá y Estados Unidos. Semanario Universidad. https://historico. semanariouniversidad.com/sin-categoria/costa-rica-rifar-viajes-para-atraer-turistas-de-canad-y-estados-unidos/

Donaire, A. (2012). Turismo cultural. Entre la experiencia y el ritual. Barcelona: Vitel-la.

Eagleton, T. (1997). Las ilusiones del posmodernismo. Buenos Aires: Paidós.

Fanon, F. (2009). Piel negra, máscaras blancas. Madrid: Akal.

Freud, S. (1984). La interpretación de los sueños. Madrid: Alianza.

Foucault, M. (2006). Seguridad, territorio y población. Buenos Aires: Fondo de Cultura Económica.

Gisolf, M. (2012). Las Certificaciones de sostenibilidad. http:/ /www.tourismtheories.org/?p=470\&lang=es

González-Casanova, P (2006). El colonialismo interno. Buenos Aires: CLACSO.

Grüner, E. (2002). El fin de las pequeñas historias. De los estudios culturales al 
retorno (imposible) de lo trágico. Buenos Aires: Paidós.

Gramsci, A. (1986). Cuadernos de la cárcel. México D.F.: Era.

Harnecker, M. y Lizana; M. (2001). Identidad psicosocial ante el desarrollo turístico: relación de la percepción del fenómeno del turismo con el proceso de conformación de identidad psicosocial en un grupo de jóvenes escolarizados de 16 a 18 años de la zona de Quepos. [Tesis de Grado Universidad de Costa Rica no publicada] Licenciatura en Psicología.

Harvey, D. (2007). Breve historia del neoliberalismo. Madrid: Akal Editores.

Hellín, P. y Martínez, S. (2009). Marca turística y movie maps. Revista signos do consumo, 1 (2), 1-18.

Instituto Nacional del Turismo (ICT). (2010). Anuario Estadístico de Turismo 2009. San José: ICT.

Instituto Nacional de Estadística y Censos (INEC). (2011). Anuario estadístico 2010. San José: Autor.

Marx, K. (2008). Contribución a la crítica de la economía política. Madrid: Siglo XXI.

Mignolo, W. (2003). Historias locales/diseños locales. Colonialidad, conocimientos subalternos y pensamiento fronterizo. Madrid: Akal.

Montero, M. (2006). Teoría y práctica de la psicología comunitaria. La tensión entre la comunidad y la sociedad. Buenos Aires: Paidós.

Morales, A., Kandel, S., Ortiz, X., Díaz, O. y Acuña G. (2011). Trabajadores migrantes y megaproyectos en América Central. San Salvador: PNUD, UCA.

Navarro, S (2013). “Turismo e inmigración en Playa Matapalo, Sardinal, Costa Rica. Resistencias comunitarias y laborales". Anuario de Estudios Centroamericanos, 39, 263-287.

Organización Mundial del Turismo (OMT), (2012). Panorama mundial del turismo 2011. http://dtxtq4w60xqpw.cloudfront.net/sites/all/files/pdf/unwto_highlights12_sp_lr.pdf

Oreamuno, Y. (1999). El ambiente tico y los mitos tropicales. Heredia, Costa Rica: EUNA.

Pereido, X. y de León, C. (2007). La construcción imaginaria del lugar turístico: Kuna Yala. Revista Tareas Cela, 127, 61-96.

Ramírez, A. (2008). Análisis de conflictos socio-ambientales relacionados con el aprovechamiento y la contaminación de los recursos hídricos en Guanacaste (1997-2006). [Tesis de Grado Universidad de Costa Rica no publicada]. 
Ramírez, A. (2010). ¿Quiebre o continuidad en el estilo de desarrollo? El caso del turismo en Costa Rica. Manuscrito no publicado.

Ramiro, P. y Pulido, A. (2009). La responsabilidad social corporativa de las multinacionales españolas en Colombia. Bogotá: Observatorio de Multinacionales en América Latina (OMAL), Asociación Paz con Dignidad.

Ramón, G. (2012, 18 de marzo). Turismo cambia sus esquemas. Industria nacional empieza a ver y conocer nuevos hábitos de visitantes extranjeros tras la crisis. El Financiero. http://wvw.elfinancierocr.com/ef_archivo/2012/ marzo/18/economia3097329.html

Raymond, N. (2004). Perú y Costa Rica. Geopolítica del desarrollo turístico en América Latina. Cuadernos Geográficos, 35 (2), 55-72.

Revista Summa (2011, 4 de enero). Agencia encargada de marcas Marriot y Toyota hará publicidad para Costa Rica. Revista Summa. http://www.revistasumma.com/economia/8406-agencia-encargada-de-marcas-marriot-y-toyota-hara-publicidad-para-costa-rica.html

RIU. (2011). Dossier de Prensa. http://www.riu.com/es/binaris/

RIU. (2012). Dossier de Prensa. http://www.riu.com/es/binaris/Dossier Espanol_2012_tcm49-85450.pdf

Rivers-Moore, S. (2007). No Artificial Ingredients?: Gender, Race and Nation in Costa Rica's International Tourism Campaign. Journal of Latin American Cultural Studies, 16(3), 341 - 357

Rodríguez, I, (2012, 14 de junio). Costa Rica es nuevamente el país más feliz del mundo, según indice 'Happy Planet'. La Nación. http:/ / www.nacion. com/2012-06-14/AldeaGlobal/Costa-Rica-es-nuevamente-el-paismas-feliz-del-mundo--segun-indice--Happy-Planet-aspx

Rodríguez, D. (2011). Capitalismo Verde: una mirada a la estrategia del BID en cambio climático. Bogotá: Censat Agua Viva - Amigos de la Tierra Colombia.

Said, E (2002). Orientalismo. Barcelona: Penguin.

Tecnitur (2012). "Felicidad", eje de la campaña de publicidad y promoción turística de Costa Rica. http://tecnitur.com/site/articulo.php?id=87

Todorov, T. (2003). Nosotros y los Otros. Reflexión sobre la diversidad humana. México D.F.: Siglo XXI.

Parker, I. (2005). Qualitative Psychology: Introducing Radical Research. Maidenhead, Inglaterra: Open University.

Parker, I. (1996). Discurso, Cultura y Poder en la Vida Cotidiana. En A. Gordo-López y J. L. Linaza (eds), Psicología, Discurso y Poder: metodo- 
logías cualitativas, perspectivas críticas. Madrid: Visor, 79-92.

Prensa Libre (2010, 26 de noviembre). Costa Rica tiene mejor marca país. http:/ /www.prensalibre.com/economia/Costa-Rica-mejor-marca-pais_0_379162084.html

Quijano, A (2000). Colonialidad del poder, eurocentrismo y América Latina. En E. Lander (comp.) La colonialidad del saber: eurocentrismo y ciencias sociales. Buenos Aires: CLACSO.

Raymond, N. (2004). Perú y Costa Rica. Geopolítica del desarrollo turístico en América Latina. Cuadernos Geográficos, 35 (2), 55-72.

Rodríguez, I, (2012, 14 de junio). Costa Rica es nuevamente el país más feliz del mundo, según indice 'Happy Planet'. La Nación. http://www.nacion. com/2012-06-14/AldeaGlobal/Costa-Rica-es-nuevamente-el-paismas-feliz-del-mundo--segun-indice--Happy-Planet-.aspx

Valles, M. (1997). Técnicas cualitativas de investigación social: reflexión metodológica y práctica profesional. Madrid: Síntesis.

Vargas, G. (2006). La actividad turística en América Central: Desarrollo y características. Anuario de Estudios Centroamericanos, Universidad de Costa Rica, 32, 9-35.

Van Dijk, T. (2008). Ideología y discurso. Un enfoque multidisciplinario. Barcelona: Ariel.

Wallerstein, I. (2005). Análisis de sistema-mundo. Una introducción. Madrid: Siglo XXI.

Žižek, S. (2007). En defensa de la intolerancia. Madrid: Sequitur.

Žižek, S. (2005). El sublime objeto de la ideología. Buenos Aires: Paidós.

Žižek, S. (2004). El acoso de las fantasías. México D.F.: Siglo XXI.

SANTIAGO NAVARRO CERDAS es costarricense. Egresado de la Maestría Profesional en Psicología Comunitaria de la Universidad de Costa Rica. Licenciado en Psicología por la Universidad de Costa Rica. Profesor de la Escuela de Psicología de la Universidad de Costa Rica. Psicólogo social del Centro de Derechos Sociales de la Persona Migrante (Cenderos). 